\title{
Best Practices of CSR Reporting in Romania
}

\author{
Gyöngyvér Erika TŐKÉS \\ Sapientia Hungarian University of Transylvania \\ Cluj-Napoca, Romania \\ e-mail: gyongyvert@ms.sapientia.ro
}

\begin{abstract}
The aim of the study is to examine the content and quality of online CSR reports of the eight large companies with the highest CSR index scores in Romania in 2020. The CSR reports of the eight large companies examined were analysed on the basis of two types of web content: on the one hand, on the basis of CSR content published on the company website and on the other hand on the basis of data published in sustainability or CSR reports uploaded to the website. The research method was thematic content analysis. The analysis criteria of the mentioned content were developed on the basis of the reporting principles of the GRI framework and the ISO 26000 standard. The findings showed that the principles of content and quality of non-financial reporting prevailed in the sustainability reports, while the data published on the websites was more for wider information.
\end{abstract}

Keywords: CSR reporting, sustainability reporting, EU non-financial reporting, Romania, best practices

\section{Introduction}

The coronavirus pandemic has highlighted humanity's responsibility to sustain the planet. Ensuring sustainability also depends crucially on finding financial and nonfinancial reserves to ensure the success of implementation (UN, 2015). To meet sustainability goals, large companies are able to mobilize a diverse and significant amount of resources, which effort takes the form of corporate social responsibility (CSR).

Corporate social responsibility (CSR) encompasses voluntary activities by companies that are not purely financial and that society as a whole expects companies to undertake in relation to governance, social and environmental issues (Cornelissen, 2020: 282). The numerous ethical scandals surrounding large multinational corporations have led to increasing pressure on companies to take responsibility for social and environmental issues beyond their narrow economic interests (CSR, 2013: 801). According to the European Communication 
Monitor 2020 report, the second most important issue for corporate leaders is CSR communication, which closely follows the topic of building trust with the business environment (ECM, 2020: 74).

The European Union's (EU) CSR strategy for 2011-2014 sets out the voluntary nature of corporate social responsibility but strongly recommends that large companies pay attention to the social and environmental impacts of corporate activities (EU, 2011: 8). A few years later, the EU clarifies its position on corporate social responsibility in its Directive 2014/95/EU on non-financial reporting (NFRD). Under that Directive, large European companies with more than 500 employees have been invited to report non-financially from 2017 onwards.

The implementation of corporate social responsibility takes place in several steps. The design and implementation phase is followed by the reporting and communication phase (Bernhart-Maher, 2011). In order to make corporate stakeholders aware of their CSR initiatives, companies disclose their CSR efforts (CSR, 2013: 801). Disclosure of CSR activities is a valuable tool for tracking progress while having an incentive effect to improve a company's CSR performance. At the same time, CSR reporting also contributes to maintaining a positive reputation and strengthens the commitment of internal and external stakeholders.

Research reveals that the amount of disclosure does not adequately reflect the quality of disclosure (Rezaee-Tuo, 2019). Academic examination of published CSR data is of paramount importance, as it is often the case that companies disclose incomplete and unreliable information in CSR reports (Michelon et al., 2015; García-Sánchez et al., 2019). CSR reporting provides accountability to corporate stakeholders and transparency of corporate operations only in the case of a meaningful approach; otherwise it provides the communication of visible and selected information that meets societal expectations (Ashforth-Gibbs, 1990: 181). In CSR reporting, the use of recognized frameworks does not guarantee the disclosure of relevant, comparable, and credible information and does not automatically imply alignment of corporate strategies with social values and norms (Ahmad et al., 2012: 37).

The aim of the present study is to examine the web-based CSR reporting of the eight large companies with the highest CSR index value in Romania in 2020 in terms of quality and content. Large companies in Romania with the best CSR performance were selected on the basis of CSR index values established by the Azores Sustainability and CSR Services Agency (Azores, 2020). The Azores is the only independent Romanian agency that has tracked the CSR performance of large Romanian companies over the past five years under the GRI framework. In 2020, the Agency calculated the CSR index of 700 large Romanian companies. In the research summarized in the present study, the study sample reached the highest CSR index value in 2020. The CSR content published on the websites of these companies and the 2019 sustainability reports uploaded to the websites were analysed using the method of thematic content analysis (Anderson, 2007). 
The structure of the paper is as follows: in section 2, the concept of CSR reporting, in section 3 the research methodology, in section 4 the results of the thematic content analysis, and in section 5 the conclusions of the research are presented.

\section{CSR Reporting}

In its 2011 CSR strategy, the EU defines CSR as "the responsibility of enterprises for their impact on society" (EU, 2011: 7). CSR is a voluntary commitment by companies to act in accordance with the principles of sustainability, to act honestly, and to take specific corporate actions in order to protect the environment and contribute to the well-being of the society around them. CSR is a corporate tool to promote sustainable development.

CSR reporting refers to the regular disclosure of information about a company's governance, social and environmental performance (CSR reporting, 2013: 801). CSR information is published in the form of separate sections of annual reports, corporate websites, and standalone sustainability or CSR reports. Since 2015, companies have been preparing sustainability reports that also include information on CSR areas. Sustainability reports also cover non-financial aspects of the economic operation of companies. For corporate stakeholders, sustainability or CSR reports are an easily accessible source of information that provides an opportunity to assess the impact of companies on society and the environment (EU, 2014: 1). The reporting requirement for companies is to take into account the information needs of all stakeholders, e.g. customers, suppliers, investors, employees, local community, municipalities, advocacy groups, public authorities, vulnerable groups, social partners, representatives of civil society, etc.

In the EU, the adoption of the NFRD has created the conditions for sustainability and CSR reporting. The NFRD defines areas of non-financial information that are "environmental, social and employment issues, respect for human rights, the fight against corruption and bribery" (EU, 2014: 2). The areas of non-financial information are also the core areas of sustainability reports. Among the nonfinancial areas, CSR areas cover social and environmental issues (CSR, 2013; Corporate Social Responsibility, 2013).

The NFRD does not provide actual indicators for reporting to help companies assess their position or progress in the field of sustainability and corporate social responsibility, but it provides examples of how initiatives in certain non-financial areas are reported. At the same time, it recommends the use of internationally recognized frameworks for the preparation of non-financial reporting such as "International Organization for Standardization ISO 26000, the International Labour Organization's Tripartite Declaration of Principles concerning Multinational Enterprises and Social Policy, the Global Reporting Initiative (GRI)” (EU, 2014: 2). 
The NFRD "exempts subsidiaries from their reporting obligations if their parent company reports for the whole group, including subsidiaries" (EU, 2014: 2).

The currently most widespread sustainability and CSR reporting framework has been developed by the Global Reporting Initiative (GRI), an international independent organization under the auspices of the United Nations, which is a constantly updated standard (CSR, 2013: 804). The ISO 26000 standard has also been widely used in the preparation of CSR reports. The fundamental difference between the GRI and the ISO 26000 standard is that while the GRI defines the actual indicators for sustainability reporting, the ISO 26000 standard sets out the measures and expectations that can be expected from socially responsible companies to address CSR areas (ISO and GRI 2014: 8; Henriques (ed.), 2011: 149).

High-value sustainability and CSR reporting requires adherence to a number of principles (ISO and GRI, 2014: 8). Both the GRI framework and the ISO 26000 standard specify the principles that form the basic requirements for nonfinancial reporting. ISO 26000 recommends the disclosure of information on social responsibility in a comprehensible, accurate, balanced, timely, accessible, and comparable form. The GRI reporting principles can be divided into two groups and are explained in more detail. The GRI principles for content include stakeholder involvement, presentation of the sustainability environment, validation of materiality, and striving for completeness of information. The GRI principles that ensure the quality of reporting are accuracy, balance, ensuring the transparency and comparability of data, building on available sources, and timeliness (GRI, 2020: 7).

Table 1 summarizes the areas and topics of non-financial information defined by the GRI framework and ISO 26000. The list of non-financial areas and topics follows the ISO 26000 standard; however, the indicators of the GRI framework are compatible with the areas listed in the table (ISO and GRI, 2014: 25). Following the ISO 26000 standard is more common among European countries, while the use of the GRI reporting framework is widespread in the USA (Ogarca-Puiu, 2017: 12). It is common in European countries for large companies to be ISO 9001 (quality) or ISO 14001 (environmental) certified, which in many respects meet the requirements of the ISO 26000 standard (Henriques (ed.), 2011: 131).

Reporting is just one but an extremely important element of CSR communication (Henriques (ed.), 2011; Bernhart-Maher, 2011). The effectiveness of CSR communication also depends on the channel of disclosure. In the renewed media environment, in addition to traditional channels, more and more companies choose to publish web-based CSR reports. This form of publication has a number of advantages over traditional printed publications, such as being environmentally friendly, allowing for regular updates, and incorporating interactivity, which are becoming increasingly important for communication with stakeholders. In the case of web-based sustainability and CSR reports, an important issue is the application of reporting principles (CSR reporting, 2013: 809). 
Table 1. Non-financial areas based on the ISO 26000 standard and the GRI framework

\begin{tabular}{|c|c|}
\hline CSR areas & Topics \\
\hline Organizational governance & $\begin{array}{l}\text { Organizational profile, strategy, and values } \\
\text { Decision-making structures and processes } \\
\text { Management approach } \\
\text { Register of organizational stakeholders }\end{array}$ \\
\hline $\begin{array}{l}\text { Economic issues and fair } \\
\text { operating practices }\end{array}$ & $\begin{array}{l}\text { Responsible economic operation } \\
\text { Anti-corruption } \\
\text { Responsible political engagement } \\
\text { Fair competition } \\
\text { Respect for property rights } \\
\text { Validating CSR in the value chain }\end{array}$ \\
\hline Environmental issues & $\begin{array}{l}\text { Pollution prevention } \\
\text { Sustainable use of resources (raw materials, energy, } \\
\text { water) } \\
\text { Climate change mitigation and adaptation } \\
\text { Environmental protection, biodiversity, and natural } \\
\text { habitat restoration }\end{array}$ \\
\hline Social issues: labour issues & $\begin{array}{l}\text { Employment and employment relations } \\
\text { Working conditions and social protection } \\
\text { Social dialogue } \\
\text { Occupational health and safety } \\
\text { Human development and training in the workplace }\end{array}$ \\
\hline Social issues: human rights & $\begin{array}{l}\text { Due diligence } \\
\text { Human rights risk situations } \\
\text { Avoiding complicity } \\
\text { Resolving grievances } \\
\text { Avoiding exclusion and protecting vulnerable groups } \\
\text { Protection of civil and political rights } \\
\text { Protection of economic, social, and cultural rights } \\
\text { Ensuring fundamental employment rights }\end{array}$ \\
\hline $\begin{array}{l}\text { Social issues: consumer } \\
\text { issues }\end{array}$ & $\begin{array}{l}\text { Fair marketing, factual and impartial information, and } \\
\text { fair contractual practices } \\
\text { Protecting the health and safety of consumers } \\
\text { Sustainable consumption } \\
\text { Consumer service, support, complaint and dispute } \\
\text { resolution } \\
\text { Protecting consumers' data and privacy } \\
\text { Access to basic services } \\
\text { Consumer education and awareness raising }\end{array}$ \\
\hline $\begin{array}{l}\text { Social issues: community } \\
\text { development and } \\
\text { involvement }\end{array}$ & $\begin{array}{l}\text { Community involvement } \\
\text { Development of education and culture } \\
\text { Job creation and skills development } \\
\text { Technology development and access } \\
\text { Wealth and income generation } \\
\text { Healthcare development } \\
\text { Social investments }\end{array}$ \\
\hline
\end{tabular}


The credibility of CSR reporting is enhanced by the involvement of third parties in the implementation and disclosure of CSR efforts. CSR activities implemented in combination with advocacy or NGOs, reports of employees committed to the company's CSR initiatives, and independently audited sustainability and CSR reports have greater credibility (Anwar-Malik, 2020: 4).

\section{Methodology}

The research presented in this study uses a qualitative approach and relies on a non-intrusive data collection method. The aim of the research is to examine the CSR reporting of the eight large companies with the highest CSR index value in Romania in 2020 in terms of content and quality. Based on the assessment of the Azores Sustainability and CSR Services Agency, the below listed eight large companies can be considered as best practices of CSR reporting in Romania.

Table 2. Sample composition

\begin{tabular}{lllc}
\hline Name of the company & Country of origin & Sector & $\begin{array}{c}\text { CSR index value } \\
\text { (max. 100) }\end{array}$ \\
\hline Coca Cola Romania & USA & Beverages & 98 \\
\hline Kaufland Romania & Germany & Food retail & 98 \\
\hline HeidelbergCement Romania & Germany & Construction & 95 \\
\hline Grupul CEZ Romania & Czech Republic & Energy & 92 \\
\hline Raiffeisen Bank Romania & Austria & Financial & 92 \\
\hline Romgaz & România & Energy & 89 \\
\hline Telekom Romania & Germany & Telecommunication & 86 \\
\hline Lidl Romania & Germany & Food retail & 85 \\
\hline
\end{tabular}

Source: Azores, 2020: 10

The CSR reporting of the eight companies surveyed was analysed based on two types of web content: CSR content published on the company's website and data provided in sustainability or CSR reports uploaded to the website. The data analysis method was thematic content analysis. The data collection and analysis period was May 2021.

The use of websites as a research data source was justified by the fact that they are the most commonly used self-controlled media channel for companies to communicate directly on strategy and CSR (ECM, 2020; Georgiadou-Nickerson, 2020; Papp-Váry, 2019; Garcia-Garcia, 2017; Bravo-Matute, 2012; Hou-Reber, 2011). The corporate website is also preferred by the public as a source of 
information for communicating CSR activities (Kim-Ferguson, 2014: 4; KimFerguson, 2018: 555).

Compared to the study of social media communication, the thematic content analysis of corporate websites predominates in the Romanian studies, as companies engage in one-way communication on CSR issues and do not focus on establishing dialogue with corporate stakeholders in social media (Şerban, 2016: 31). This is also supported by a survey conducted by CSR Media (2020), according to which a significant number of Romanian companies continue to communicate CSR on their websites.

The analytical criteria of the reporting of CSR "gold medal" companies in Romania have been formulated on the basis of the reporting principles of the GRI framework and the ISO 26000 standard.

Table 3. Content and quality criteria of CSR reporting

\begin{tabular}{|c|c|}
\hline Content criteria of the CSR reporting (A) & Quality criteria of the CSR reporting (B) \\
\hline $\begin{array}{l}\text { a) Involvement of stakeholders } \\
\text { (identification of stakeholders - external, } \\
\text { internal - impartial assessment of their } \\
\text { expectations) }\end{array}$ & $\begin{array}{l}\text { a) Accuracy (data are detailed, and the } \\
\text { method of calculation can be followed) }\end{array}$ \\
\hline $\begin{array}{l}\text { b) Presentation of the sustainability } \\
\text { environment (contribution to } \\
\text { sustainability now and in the future, } \\
\text { at local, regional, and global level, in } \\
\text { different areas of sustainability) }\end{array}$ & $\begin{array}{l}\text { b) Balance (both positive and negative } \\
\text { aspects of CSR activity are explored, not } \\
\text { just a selection of good results) }\end{array}$ \\
\hline $\begin{array}{l}\text { c) Materiality validation (presentation of } \\
\text { relevant issues related to the social and } \\
\text { environmental impact of the organization } \\
\text { and on which stakeholders make } \\
\text { decisions) }\end{array}$ & $\begin{array}{l}\text { c) Transparency (classification of CSR } \\
\text { activities by thematic area or stakeholder) }\end{array}$ \\
\hline $\begin{array}{l}\text { d) Striving for completeness (reporting } \\
\text { on all relevant issues during the reporting } \\
\text { period) }\end{array}$ & $\begin{array}{l}\text { d) Comparability (published data follow } \\
\text { an international standard: ISO26000, GRI, } \\
\text { etc.) }\end{array}$ \\
\hline
\end{tabular}

e) Verifiability (availability of data sources for published data)

f) Timeliness (reference of data to precise periods)

g) Strengthening credibility by involving third parties, quality assurance systems 


\section{Findings}

\subsection{Content of CSR Reporting of the Surveyed Romanian Companies}

In the following, we present the fulfilment of the content and quality criteria of CSR reporting based on the joint observation of the data published under the sustainability or CSR menu items and in the 2019 sustainability reports uploaded on the websites. The surveyed large companies that are good examples of CSR in Romania had a separate sustainability or CSR menu item on their website and a downloadable 2019 sustainability report. It is worth noting that the companies surveyed did not publish CSR reports but sustainability reports that integrated CSR-related areas.

It can be stated that the data published under the sustainability or CSR menu item of corporate websites were more informative. The CSR initiatives, which can be limited in different areas and over time, as well as the actual results, were presented in detail in the annual sustainability reports. The theoretical chapter of the study discussed that CSR is a tool for companies to ensure sustainability. Six companies already had a tradition of sustainability reporting, and sustainability reports for 2017 and 2018 were also available on their websites. The language of the sustainability reports is Romanian in six cases, indicating that the information was primarily aimed at the Romanian public. For two companies, Kaufland and Raiffeisen Bank, the report was in English, referring to the global nature of the communication. It is important to emphasize that the content of the reports was adapted to the situation in Romania, and the published sustainability/CSR initiatives responded to the challenges of local circumstances.

Table 4. The motto of the CSR activities of the surveyed companies

\begin{tabular}{ll}
\hline Name of the company & Motto \\
\hline Coca Cola Romania & Together for the future. \\
\hline Kaufland Romania & Our actions do the talking. \\
\hline HeidelbergCement Romania & At the foundation of everything that lasts. \\
\hline Grupul CEZ Romania & CEZ Green Generation. \\
\hline Raiffeisen Bank Romania & Digital solutions for responsible banking. \\
\hline Romgaz & The energy of a dynamic future. \\
\hline Telekom Romania & Experiencing together. \\
\hline Lidl Romania & Generations that deserve a better future. \\
\hline
\end{tabular}

Source: author's compilation 
The slogans of the sustainability reports summarized in simple terms the attitude of the companies surveyed towards sustainability and social responsibility. The slogans draw attention to the future and the new generation and reflect the relationship of companies to these two concepts.

A / a) Involvement of stakeholders. Looking at the websites, it can be observed that the companies surveyed addressed two main target groups, namely employees and customers. Each company provided content in a separate menu item to these two functional target groups. Three companies (Raiffeisen Bank, Romgaz, Telekom) also created a separate menu item for investors, during which financial data, analyses of their economic performance, and annual financial reports were published. The sustainability reports mapped the full range of stakeholders in the companies surveyed and outlined the ways to communicate. The websites of the companies surveyed also contained codes of ethics and conduct that regulated the relationship between companies and their target groups.

Tools to facilitate two-way communication with customers were also present on corporate websites. For all companies, the website was linked to Facebook, Twitter, and YouTube. In the case of some companies (Coca Cola, Kaufland, Raiffeisen Bank, CEZ Group), online customer service tools were also available, e.g. transmission of personalized content subject to registration, personalized e-mail communication, telephone service, chat service, or even service robots. However, it was not typical to maintain online communities, forums or to run professional blogs.

A / b) Presentation of the sustainability environment. The large companies surveyed included in their sustainability reports a presentation of the global or regional environment for sustainability. The surveyed companies also presented the situation in Romania in each sustainability area and adjusted the reports to the Romanian environment. In presenting the non-financial results achieved in 2019, the companies summarized the period during which they apply sustainability aspects in their activities and also projected the development rates planned for the next period. The surveyed companies also highlighted areas of sustainability that are important to them: e.g. in the case of CEZ Group, Romgaz, Telekom, and Raiffeisen Bank, the pursuit of digital transformation and the possibilities of ensuring sustainability in this area were analysed.

A / c) Validation of materiality. An important step in preparing a sustainability report is to identify topics that are relevant to the company's economic, social, and environmental impacts and to influencing stakeholder decisions. Social responsibility is possible if companies are aware of the needs and expectations of stakeholders and have a regular dialogue about it. The listing of the stakeholders of the companies and the identification of their needs did not appear on the websites of the eight companies examined; however, these issues were presented in detail in the materiality matrix chapter in the sustainability reports. Current sustainability/ 
CSR topics for companies were ranked based on stakeholder dialogue, starting from the company's direct and indirect impacts on environment and society.

The Romanian CSR gold medal companies have indicated on their website the areas of sustainability/CSR in which they have operated. These include organizational governance, environmental protection, workforce and work processes, consumer affairs, and community development. Sustainability reports included a presentation of the sustainability strategy of companies, along with the actual commitments they wanted to achieve over time. The formulated sustainability strategies were based on the UN's Transforming Our World: The Requirements for a Sustainable Development Agenda to 2030 (UN, 2015). Their performance in reducing social and environmental impacts has been compared by companies to recent sustainability performance and commitments to be made at a future date (2030: Kaufland, HeidelbergCement, Telekom, Coca-Cola, Lidl; 2025: Raiffeisen Bank).

The sustainability reports of the surveyed companies also covered the topic of economic issues and the commitment to fair operating practices. All the companies examined were characterized by the incorporation of the principles of social responsibility into the corporate philosophy. Achieving excellent business performance, paying attention to customers, and contributing to social well-being were at the forefront of companies' mission and vision. Attention paid to environmental issues has appeared in the missions of five out of eight companies. The companies emphasized compliance with fair competition rules (e.g. HeidelbergCement, Kaufland, Lidl, Romgaz, CEZ Group, Coca-Cola, Raiffeisen Bank), contribution to the fight against bribery (e.g. HeidelbergCement, Kaufland, Romgaz, CEZ Group, Coca-Cola, Raiffeisen Bank), and the enforcement of sustainability values in the value chain (e.g. HeidelbergCement, Kaufland, Romgaz, Telekom, Coca-Cola, Raiffeisen Bank). Companies have also provided training of fair competition to managers as part of the fight against bribery.

In the field of environmental protection, companies have reported on the following initiatives: pollution prevention activities, energy efficiency, the use of alternative energy sources, the conservation of natural resources, and efficient waste management. HeidelbergCement highlighted the use of environmentally friendly equipment and technologies, and Lidl highlighted the creation of the EDGE award-winning environmentally friendly business premises. In the case of companies belonging to the beverage and food industry (e.g. Coca Cola, Lidl, Kaufland), priority has been given to the distribution of green products. Half of the companies surveyed (Coca Cola, CEZ Group, HeidelbergCement, Raiffeisen Bank) sponsored environmental projects led by green organizations or local authorities.

In sustainability reports, companies have dedicated a separate chapter to human rights issues or integrated them with social issues. The key initiatives were to ensure equal opportunities and diversity, as well as fundamental labour and 
consumer rights. All companies surveyed paid close attention to the safety of work processes and health protection. All companies reported providing comfortable and safe working conditions for their employees, creating equal opportunities for people from different socio-demographic groups, providing training for individual and professional development, predictable career planning opportunities, and a number of employment benefits. Contact with the workforce is a prominent area of CSR gold medal companies, and workforce satisfaction has been a priority for some of the companies (HeidelbergCement, Lidl, Raiffeisen Bank).

The most common forms of customer responsibility were thorough responsible marketing, the provision of quality products and services, and increased attention to customer needs. Four of the eight companies focused on raising and educating customers (Coca Cola, Telekom, CEZ Group, HeidelbergCement). Kaufland, Lidl, Telekom, Raiffeisen Bank, Romgaz, and CEZ Group conducted surveys to measure consumer satisfaction. Telekom, Raiffeisen Bank, Romgaz, and CEZ Group have improved the quality of services provided to consumers through digital transformation.

Companies have contributed to social well-being in two ways: on the one hand, they have initiated rural development and skills development projects; on the other hand, in order to solve the problems of local communities, companies also offered skills, i.e. employees of the companies volunteered in the local communities (six of the eight companies). Community development projects also targeted the development of technological infrastructure (e.g. HeidelbergCement). The companies surveyed made a significant contribution to the development of digital skills of disadvantaged target groups in local communities, and each company supported several educational projects. Six of the eight companies contributed to the development of healthcare (HeidelbergCement, Coca Cola, CEZ Group, Kaufland, Romgaz, Telekom). Support for sports and art events also appeared in the case of five companies (CEZ Group, HeidelbergCement, Kaufland, Romgaz, Raiffeisen Bank).

A / d) Striving for completeness. The sustainability reports presented the results for the period under review in all non-financial areas. The principle of completeness was met in the sustainability reports, which strictly followed the GRI framework.

\subsection{The Quality of CSR Reporting of the Surveyed Romanian Companies}

$B$ / a) Accuracy. The numerical results of the CSR activities and the amount of resources devoted to these activities did not appear on the websites, but the specific information was included in the sustainability reports uploaded thereon. The source of the data was the reporting companies; however, the methodology for calculating the indicators was not always included in the reports. Of the eight companies examined, the HeidelbergCement report stated that publishing an 
accurate calculation of the indicators would jeopardize their market position. The sustainability reports of the surveyed companies provided statistics, calculated indicators, subsidy amounts, and the number of beneficiaries for each sustainability area.

$B$ / b) Balance. To ensure transparency, companies should also indicate adverse facts and figures when presenting CSR activities. None of the eight companies surveyed reported difficulties and barriers to CSR activities. Sustainability reports also did not report any spill-over effects that would have resulted in a high level of dissatisfaction among corporate stakeholders.

$B$ / c) Transparency. The principle of transparency has been applied both in the editing of sustainability/CSR menu items and in the compilation of sustainability reports. Thematic separation of CSR initiatives has been a feature of both websites and sustainability reports. The structure of the sustainability reports followed the chapters of the GRI framework. The structure of the reports was uniform, consisting of a presentation of the organizations and the governance of the organization, followed by answers to economic questions and fair operating practices, as well as environmental and social issues. Regarding CSR reporting, sustainability reports can be considered as the main source of information. The transparency of the data reported was enhanced by representation in graphical and visual models and the provision of interactive links for further information. Transparency was also reflected in the fact that sustainability reports for the previous period (2015-2018) were also available on the companies' websites, under the sustainability/CSR menu item.

$B$ / d) Comparability. The data of the companies surveyed were comparable, as the surveyed companies used the GRI framework to prepare their non-financial reports. The sustainability reports of all the companies surveyed ended with an index of GRI indicators, which allowed the CSR results to be traced and compared.

$B /$ e) Verifiability. The data published in the sustainability reports came from the companies' own resources, but the reports were independently audited for just two companies (Kaufland, Lidl).

$B / f)$ Timeliness. In the case of the examined companies, the principle of timeliness prevailed in the sustainability reports, and the dating of the data was typical. The frequency of the reporting and the dates of the last reports were also specified. The analysed sustainability reports covered the period from 1 January to 30 December 2019. In the case of the data presented on the websites under the sustainability/CSR menu item, the principle of timeliness was not always enforced, as the date of the shares could be partially identified.

$B$ / g) Credibility, involvement of third parties. Stakeholders' trust in the company is positively influenced by the fact that the companies have quality assurance certificates and awards for their field, as well as membership in recognized international professional organizations. Among the Romanian CSR gold medal 
companies, HeidelbergCement, Romgaz, Telekom, and Coca Cola had various ISO certificates (ISO 9001, ISO 14001, ISO37001). It was more common to have professional awards (e.g. HeidelbergCement, Kaufland, Coca Cola, Raiffeisen Bank) and to present partnerships with industry-specific international organizations (e.g. HeidelbergCement, Lidl, CEZ Group, Coca Cola, Raiffeisen Bank). Telekom has implemented community programmes with the Red Cross. Kaufland and HeidelbergCement were founding members of the Sustainability Embassy in Romania, an association that disseminates and supports the organizational culture of sustainability in Romania. The sustainability report of Coca Cola and Raiffeisen Bank was also prepared with the support of the said association. Presentation of the results of CSR activities through actual cases occurred in reports of half of the companies (CEZ Group, Telekom, Coca Cola, Raiffeisen Bank). Beneficiaries' reports were not typical on the websites or in the sustainability reports.

\section{Discussion and Conclusions}

The aim of this study was to examine the CSR reporting of eight Romanian companies that can be considered as good examples based on their achieved CSR index value. Of the eight companies, three belonged to the food and beverage industry, two to the energy industry, one to the construction industry, one to the telecommunications industry, and one to the banking sector. We were not able to observe sectoral differences between the companies.

The research was based on the idea that undertaking CSR activities can transform the overall operation of companies and not just an apparent activity to maintain corporate reputation. By presenting the content and quality characteristics of CSR reporting of CSR good examples in Romania, a way of best practice CSR reporting was highlighted. Six of the eight companies surveyed had disclosed non-financial information for several years and had experience in CSR reporting. It was observed that the surveyed companies provided more general information to stakeholders under the Sustainability/CSR menu item on their website, and the detailed information was provided in the sustainability reports. The enforcement of the content principles of high-quality sustainability reporting was partially present on the websites. These companies used the GRI framework to disclose their non-financial information, and only two companies were subject to external audit of their reporting, which would have increased the credibility of the report.

The sustainability reports included a list of corporate stakeholders and how to contact them, but through the websites companies mainly communicated with customers and employees. The sustainability reports were adapted to the Romanian environment and included the CSR goals to be achieved for the future. The principle of materiality has been applied to varying degrees on websites and 
in sustainability reports. Relevant CSR topics were presented on the websites in a traceable way, but here mainly the commitment of the companies to CSR was emphasized. The principle of materiality was met in the sustainability reports, as the relevant CSR topics were discussed in separate chapters, and the results were compared with past performance and future targets. The pursuit of completeness was also reflected in the sustainability reports, as information was provided on all CSR topics for the reporting period. The principle of timeliness was not met on the websites, as in several cases it was difficult to identify the reference period of the CSR performances.

Most of the CSR initiatives were in the field of environment and workforce development. The most common initiatives in community development were to support educational programmes or organize activities that contribute to the development of skills and abilities in the local community. These activities contributed to the development of lagging regions in Romania, where the level of human capital development is low (World Bank, 2020: 41) and where the level of environmental awareness also needed to be improved (Ahmad et al., 2012: 75; Öllerer, 2012: 25).

The qualitative aspects of CSR reporting were also reflected in the sustainability reports. In some cases, the websites included actual results in each CSR area, but timeliness, verifiability, and comparability were difficult to establish. The principle of transparency prevailed on the websites of the surveyed companies; however, the principle of balance was less applied. In the reports, we encountered accurate company statistics and calculated indicator values for the reporting period for each CSR topic. However, it was a problem to follow the principle of balance, which raised the problem of data selection and reduced credibility. The principle of comparability also prevailed in the sustainability reports, which ended with an index of GRI indicators.

Overall, it can be concluded that the principles of CSR reporting have been applied at a high level in the sustainability reports of the surveyed companies. The reports met the content requirements set out in the GRI framework, and the quality principles of accuracy, transparency, and timeliness were applied. The level of implementation of the principles of balance and verifiability was lower. The credibility of the sustainability reports would have been greatly enhanced if the reports had been verified by independent experts.

The examination of the good examples of CSR in Romania supports the validity of reporting and serves as a guide to the practice of corporate social responsibility reporting in Romania. In the Romanian economic environment, high-quality CSR reporting is still new, and it is mainly characteristic of the Romanian branches of multinational companies and large Romania-based companies. Corporate stakeholders, and in particular the younger generations, are increasingly interested in corporate business philosophy and social responsibility, which requires rethinking 
companies' communication strategies and stakeholder engagement practices to adapt to expectations. Further development of research would be necessary in several directions. It would be important to examine the development of CSR communication over time for Romanian companies with a tradition, as well as to carry out comparative analyses of CSR communication in different economic sectors.

\section{References}

Ahmad, J.-Ali, I.-Grigore, G. F.-Stancu, A. (2012). Studierea conştiinței ecologice a consumatorilor - o analiză comparativă între România, Malaezia şi Pakistan. Amfiteatru Economic 14(31): 65-79.

Anderson, R. (2007). Thematic Content Analysis: Descriptive Presentation of Qualitative Data. <http://rosemarieanderson.com/wp-content/uploads/2014/08/ ThematicContentAnalysis.pdf> [Accessed on 20 June 2021].

Anwar, R.-Malik, J. A. (2020). When Does Corporate Social Responsibility Disclosure Affect Investment Efficiency? A New Answer to an Old Question. Sage Open, April-June: 1-14. DOI: 10.1177/2158244020931121.

Ashforth, B. E.-Gibbs, B. W. (1990). The Double-Edge of Organizational Legitimation. Organization Science 1(2): 177-194.

Azores Sustainability and CSR Services Report Romania CSR Index. (2020). $<$ https://www.theazores.ro/romania-csr-index-2020/> [Accessed on 16 March 2021].

Bernhart, M. S.-Maher, F. J. (2011). ISO 26000 in Practice. A User Guide. Milwaukee, Wisconsin: ASQ Quality Press.

Bravo, R.-Matute, J.-Pina, J. M. (2012). Corporate Social Responsibility as a Vehicle to Reveal the Corporate Identity: A Study Focused on the Websites of Spanish Financial Entities. J. Bus. Ethics 107: 129-146. https://doi.org/10.1007/s10551011-1027-2.

Cornelissen, J. (2020). Corporate Communication: A Guide to Theory \& Practice. London: Sage.

Corporate Social Responsibility. (2013). In: Idowu, S. O.-Capaldi, N.-Zu, L.-Gupta, A. D. (eds.), Encyclopedia of Corporate Social Responsibility. Berlin, Heidelberg: Springer. https://doi.org/10.1007/978-3-642-28036-8_100426.

CSR. (2013). In: Idowu S. O.-Capaldi, N.-Zu, L.-Gupta, A. D. (eds.), Encyclopedia of Corporate Social Responsibility. Berlin, Heidelberg: Springer. https://doi. org/10.1007/978-3-642-28036-8_100486.

CSR Reporting. (2013). In: Idowu, S. O.-Capaldi, N.-Zu, L.-Gupta, A. D. (eds.), Encyclopedia of Corporate Social Responsibility. Berlin, Heidelberg: Springer. DOI: 10.1007/978-3-642-28036-8_145. 
European Communication Monitor. (2020). <https://www.communicationmonitor. eu/2020/05/29/ecm-european-communication-monitor-2020/> [Accessed on 13 March 2021].

European Union. (2011). A Renewed EU Strategy 2011-14 for Corporate Social Responsibility. <https://eur-lex.europa.eu/legal-content/EN/TXT/?uri =CELEX:52011DC0681> [Accessed on 13 March 2021].

(2014). As Regards Disclosure of Non-financial and Diversity Information by Certain Large Undertakings and Groups. <https://eur-lex.europa.eu/legalcontent/EN/TXT/?uri=CELEX\%3A32014L0095> [Accessed on 13 March 2021]. (2017). Guidelines on Non-Financial Reporting (Methodology for Reporting Non-Financial Information). <https://eur-lex.europa.eu/legal-content/EN/TXT/ PDF/?uri=CELEX:52017XC0705(01)\&from=RO > [Accessed on 13 March 2021].

Garcia Garcia, M.-Carrillo-Duran, M. V.-Tato Jimenez, J. L. (2017). Online Corporate Communication: Website Usability and Content. Journal of Communication Management 21(2): 140-154.

García-Sánchez, I. M.-Gómez-Miranda, M. E.-David, F.-Rodríguez-Ariza, L. (2019). Board Independence and GRI-IFC Performance Standards: The Mediating Effect of the CSR Committee. Journal of Cleaner Production 225: 554-562.

Georgiadou, E.-Nickerson, C. (2020). Exploring Strategic CSR Communication on UAE Banks' Corporate Websites. Corporate Communications: An International Journal 25(3): 413-428.

GRI. Consolidated Set of GRI Sustainability Reporting Standards. (2020). <https:// www.globalreporting.org/> [Accessed on 20 June 2021].

Henriques, A. (ed.) (2011). Understanding ISO 26000. A Practical Approach to Social Responsibility. London: BSI.

Hou, J.-Reber, R. (2011). Dimensions of Disclosures: Corporate Social Responsibility (CSR) Reporting by Media Companies. Public Relations Review 37(2): 166-168.

ISO 26000. Social Responsibility. <http://www.iso.org/iso/home/standards/ iso26000.htm $>$ [Accessed on 20 of June 2021].

ISO and GRI. (2014). GRI G4 Guidelines and ISO 26000:2010 How to Use the GRI G4 Guidelines and ISO 26000 in Conjunction. Amsterdam: ISO.

Kim, S.-Ferguson, M. A. (2014). Public Expectations of CSR Communication: What and How to Communicate CSR. Public Relations Journal 8(3): 1-22. (2018). Dimensions of Effective CSR Communication Based on Public Expectations. Journal of Marketing Communication 24(6): 549-567.

Michelon, G.-Pilonato, S.-Ricceri, F. (2015). CSR Reporting Practices and the Quality of Disclosure: An Empirical Analysis. Critical Perspectives on Accounting 33: 59-78. https://doi.org/10.1016/j.cpa.2014.10.003.

Ogarca, R. F.-Puiu, S. (2017). Corporate Social Responsibility in the Romanian Public Sector. In: Corporate Social Responsibility in Times of Crisis. Berlin, Heidelberg: Springer, 111-125. 
Öllerer, K. (2012). Educația ecologică - între necesitate şi oportunitate. Calitatea Vieții XXIII: (1): 25-44.

Papp-Váry, Á.-Farkas, M. (2019). The Possible Ways of Country Brand Communication and Their Classification Based on the POE Model. Acta Universitatis Sapientiae, Communicatio 6: 19-40. DOI: 10.2478/auscom-2019-0002.

Rezaee, Z.-Tuo, L. (2019). Are the Quantity and Quality of Sustainability Disclosures Associated with the Innate and Discretionary Earnings Quality? Journal of Business Ethics 155(3): 763-786. https://doi.org/10.1007/s10551-017-3546-y.

Şerban, A. D. (2016). CSR as Corporate Power. A Communication View Facebook Approach: An Exploratory Study. Management Dynamics in the Knowledge Economy 4(1): 31-61.

UN. (2015). Transforming Our World: The 2030 Agenda for Sustainable Development. $<$ https://sdgs.un.org/2030agenda> [Accessed on 20 June 2021].

World Bank. (2020). The Human Capital Index 2020 Update: Human Capital in the Time of COVID-19. Washington, DC: World Bank. <https://openknowledge. worldbank.org/handle/10986/34432> [Accessed on 16 October 2021].

\section{Cite as:}

Tókés, Gy. E. (2021). Best Practices of CSR Reporting in Romania. Acta Universitatis Sapientiae, Communicatio 8: 104-120. DOI: 10.2478/auscom-2021-0008. 